\title{
Effects of Metacognition on Performance in Mathematics and Language- Multiple Mediation of Hope and General Self-Efficacy
}

\author{
Georgia Stephanou ${ }^{1} \&$ Fotini Tsoni ${ }^{1}$ \\ ${ }^{1}$ Faculty of Social and Humanities Studies, University of Western Macedonia, Greece \\ Correspondence: Georgia Stephanou, Faculty of Social and Humanities Studies, University of Western \\ Macedonia, Florina, 53100, Greece. E-mail: gstephanou@uowm.gr
}

Received: September 5, 2019

Accepted: September 29, 2019 Online Published: October 3, 2019

doi:10.5539/ijps.v11n4p30

URL: https://doi.org/10.5539/ijps.v11n4p30

\begin{abstract}
This study examined (a) students' reported use of metacognitive knowledge (declarative, procedural, conditional) and metacognitive regulation (planning, monitoring, information management, evaluation) when they are doing school work or homework, and the effect of metacognition on school performance in language and mathematics and (b) the role of hope (agency thinking, pathway thinking) in general self-efficacy, in the impact of general self-efficacy on metacognition, and in the effect of metacognition on school performance. One hundred and sixty-five 5th and 6th grade students ( 83 boys, 82 girls), randomly selected from 10 state primary schools of various regions of Greece, participated in the study. Data gathered at the second school term of the total three terms. The results revealed that: (a) the reported frequency of use of metacognitive knowledge (mainly, conditional) and metacognitive regulation (mainly, monitoring) was at a moderate extent, (b) hope (predominately, pathway thinking) was a positive formulator of general self-efficacy and of its impact on metacognition, but the influential role of the two constructs differed between and within the components of metacognition, (c) the three sets of predictors had complementary and positive effects on school performance but their relative power in influencing it varied between mathematics and language and within each school subject, with agency thinking being the most powerful predictor and (d) general self-efficacy mediated the impact of metacognition on school performance, while hope had direct impact on school performance beyond that of metacognition and general self-efficacy. The findings are discussed for their practical applications in education and future research.
\end{abstract}

Keywords: metacognition, hope, general self-efficacy, school performance

\section{Introduction}

During the last three decades, metacognition has documented as a critical contributor in self-regulated learning and successful learning (Abdellah, 2015; Dimmit \& McComick, 2012; Efklides, 2014; Efklides \& Misailidi, 2010; Gomes, Golino, \& Menezes, 2014; Panadero, 2017; Stephanou \& Mpiontini, 2017; Veenman, 2016; Veenman, Wilhelm, \& Beishuizen, 2004). Despite the differences among the researchers about the components of metacognition, they agree that it consists of two key dimensions, metacognitive knowledge and metacognitive regulation which are mainly operationalized into monitoring (metacognitive knowledge and metacognitive experience) and regulatory (goals and activation of strategies) functions (see Adler, Zion, \& Mevarech, 2016; Brown, 1987; Cleary, 2012; Efklides, 2001, 2008, 2014; Flavell, 1987; Jacobs \& Paris, 1987; Perry, 2013; Schraw \& Moshman, 1995; Tanner, 2012). Students who have well developed metacognitive knowledge and metacognitive regulatory skills and who use their metacognition they will excel academically (Alexander, 2008; Artelt, Naumann, \& Schneider, 2010; Callan \& Cleary, 2018; Carr, 2010; Efklides, 2011; Harris, 2015; Pintrich, 2002; Stephanou \& Mpiontini, 2017; Thillmann, 2008; Winne \& Nesbit, 2010; Zohar \& David, 2009).

Most researchers have focused on the role of metacognition in science learning and problem solving (Taasoobshirazi \& Farley, 2013; Zepeda, Richey, Ronevich, \& Nokes-Malach, 2015), while a limited number of studies have examined how it is related to academic achievement across the full range of academic domains. In addition, students' developmental phase and educational level are crucial in understanding that link because elementary and older students might differ in prevalence and optimal combination of the constructs of metacognition (see Bakracevic-Vukman \& Licardo, 2010; Schneider, 2008; Schneider \& Lockl, 2006; Stipek \& MacIver, 1989), and the high school context, compared to elementary school, is more autonomy-supportive, sets 
more antaconistic goals and is less supportive (Eccles \& Wigfield, 2000; Haselhuhn, Al-Mabuk, Gabriele, Groen, \& Galloway, 2007; Midgley, Anderman, \& Hicks, 1995; Stipek \& MacIver, 1989). The present research examines metacognitive knowledge and metacognitive regulation in the fifth and sixth grade students, and how metacognition influences school performance in language and mathematics.

Although metacognition documented positive relation to academic achievement and successful learning (Bruning, Schraw, \& Norby, 2011; Rosman, Mayer, \& Krampen., 2015), academic self-regulation and success are not coming without motive (Benbenutty, Cleary, \& Kitsantas, 2014; Caprara, Fida, Vecchione, Del Bove, Vecchio, Barbaranelli, \& Bandura, 2008; Cera, Mancini, \& Antionietti, 2013; Schunk \& Zimmerman, 2006; Smit, de Brabander, Boekaerts, \& Martens, 2017). Moreover, as Efklides (2011) suggests in her Metacognitive and Affective Model of Self-Regulated Learning (MASRL), the macro-level of SRL involves volitional, cognitive, motivational and affective trait-related person characteristics which also interact with micro-level process. Therefore, this study involves metacognition with self-efficacy and hope that are trait-related person characteristics and that have evidenced significant relationships with academic functioning and success.

Self-efficacy, which refers to an individual's belief in his/her ability to control challenging environmental demands by taking adaptive action (Bandura, 1997), is a crucial and proximal predictor of academic achievement. For example, high self-efficacious students get involved in more challenging and ambitious goals, insist more in pursuit the goals and, usually, get higher grades in various school subject and succeed (Coutinho \& Neuman, 2008; Jansen, Scherer, \& Schroeders, 2015; Lee, Lee, \& Bong, 2014). Although, usually, following Bandura's (1997) suggestion, self-efficacy is thought as being either task-specific or domain-specific, the concept of generalized self-efficacy, that refers to a broad and stable sense of one's ability to deal effectively with a variety of demanding situations, has been suggested by some researchers (Luszczynska, Gibbons, Piko, \& Teközel, 2004; Schwarzer \& Jerusalem, 1995; Sherer, Maddux, Mercandante, Prentice-Dunn, Jacobs, \& Rogers, 1982). In the present study, self-efficacy is perceived in its general sense.

As self-efficacy, but in a different way, past research has shown that the Snyder's (2000) cognitive goal- directed conceptualization of hope predicts goal directed behavior and student achievement (see Dixson, 2017; Feldman \& Kubota, 2015; Rand, Martin, \& Shea, 2011; Snyder, 2004; Stephanou, 2012). Hopeful students report school achievement success regarding competence, self-worth, attendance, course selection, grade, graduation rates and college going rates (Buckelew, Crittendon, Butkovic, Price, \& Hurst, 2008; Ciarrochi, Heaven, \& Davies, 2007; Kwon, 2000; Marques, Pais-Ribeiro, \& Lopez, 2011; Ong, Edwards, \& Bergeman, 2006; Pedrotti, Edwards, \& Lopez, 2008; Snyder, Shorey, \& Rand, 2006).

Overall, this study augments past research in three ways. First, despite the increased knowledge evidencing the positive role of the perception-based psychosocial factors of self-efficacy and hope in academic achievement, some aspects of how these factors influence academic outcomes are unknown (see Richardson, Abraham, \& Bond, 2012, for a review). For example, the generalizability of the association of perception-based constructs with and academic behaviors has been limitedly examined as well as how these constructs interact each other has been narrowly studied. Second, few studies have examined the contribution of metacognition into academic achievement relative to self-efficacy (see Tian, Fang, \& Li, 2018). Self-efficacy has impact on other cognitions and affect, and its influences on academic achievement behavior is also indirect (Bandura, 1997). For instance, self-efficacy proved a mediator factor of the impact of metacognition on school performance (Tian et al., 2018). Finally, to our knowledge, no study has investigated all three, metacognition, self-efficacy and hope, in prediction of school performance.

\subsection{Metacognition and Academic Achievement}

Although various conceptualizations of the term "metacognition" have been used in literature, it has been broadly defined as 'cognition about cognition' (Flavell, 1979) and refers to the regulation of one's own cognitive processes and encompasses the main constructs of meta-cognitive knowledge, metacognitive experiences and metacognitive skills / strategies (see Brown, 1978; Efklides, 2011, 2013; Flavell, 1978; Flavell, Miller, \& Miller, 2002; Jacobs \& Paris, 1987; Schneider, 2008; Veenman, 2011, 2016; Veenman, Van Hout-Wolters, \& Afflerbach, 2006; Young, 2010).

Metacognitive knowledge or metacognitive awareness refers to individuals' knowledge of their own cognitive and affective processes, may vary between tasks, strategies, goals and other relevant to achievement of a pursuit goal information, and it consists of declarative, procedural and conditional knowledge (Efklides, 2008; Perry, 2013; Tanner, 2012). Declarative knowledge focuses on "knowing that", and refers to self, task, and strategies for achievement a specific task, procedural knowledge concerns "knowing how", and contains learning strategies and execution of procedural skills, while conditional knowledge is about 'when', 'where' and 'why' to use 
certain cognitive actions or strategies (Flavell, 1979; Harris, Graham, Brindle, \& Sandmel, 2009; Holland-Joyner \& Kurtz-Costes, 1997; Pressley, Borkowski, \& Schneider, 1989; Schraw, Crippen, \& Hartley, 2006).

Metacognitive regulation refers to the actual activities that 'help control one's thinking or learning" (Schraw \& Moshman, 1995, p. 354), that is, the implementation of metacognitive knowledge in the process of self-regulated learning, and it contains the three main components of planning, monitoring and evaluating (Artelt et al., 2010; Flavell, 1979; Hacker, 1998; Pressley, Borkowski, \& Schneider, 1987; Schneider \& Artelt, 2010; Veenman et al., 2006). Specifically: (a) Planning is comprised of activating relevant background knowledge, goal setting, determining time and effort allocation and selecting appropriate strategies for learnings, (b) monitoring involves the self- testing and assessment skills necessary to control the process of learning, ensuring that things make sense within the accepted cognitive frameworks, judging whether understanding is sufficient and the selected strategy is working, and searching for connections or conflicts with what is already known and (c) evaluation (Schraw, Crippen, \& Hartley, 2006, p. 114) "refers to appraising the products and regulatory processes of one's learning" (Brown, 1987; Cera et al., 2013; Perry, 2013; Serra \& Metcalfe, 2009; Schraw et al., 2006; Tarricone, 2011; Zimmerman, 2002).

Past researchers make evident the positive influential role of metacognition in academic achievement and learning (Artelt et al., 2010; Dimmit \& McCormick, 2012; Dunlosky \& Metcalfe, 2009; Efklides, 2014; Gaskill \& Hoy, 2002; Hacker, Bol, \& Keener, 2008; Thillmann, 2008; Winne \& Nesbit, 2010) in various domains, such as mathematics (Callan \& Cleary, 2018; De, Desoete, \& Roeyers, 2000; Desoete, Roeyers, \& Buysse, 2001; Desoete, Roeyers, \& De Clercq, 2003), language and physical education (Stephanou \& Mpiontini, 2017), reading competence (Soodla, Jõgi, \& Kikas, 2016), language learning (Wang \& Han, 2017), writing and reading (Chonan \& Sawa, 2009; Harris, Santangelo, \& Graham, 2010), music (Barbara \& Alessandro, 2017), learning and performing better in the classroom (Pintrich, 2002), emotions in learning situations (Efklides, 2011, 2016; Karagiannides, Barboukis, Gourgoulis, Kosta, \& Antoniou, 2015) and problem solving (Antonietti, Ignazi, \& Perego, 2000).

Other studies (e.g., Artelt, Schiefele, \& Schneider, 2001; Veenman, Kok, \& Blöte, 2005; see also Schneider, 2010) show evidence that metacognitive knowledge and self-regulation not only are determinant factors in elementary school children but also predict math performance and reading comprehension in secondary school, independent of intellectual abilities. However, the topic of metacognitive regulation, in comparison to metacognitive knowledge, has received less attention in research on mathematical learning (Neuenhaus, Artelt, Lingel, \& Schneider, 2011; see also Tian et al., 2018).

The importance of the various components of metacognition in the academic achievement of elementary school students might differ from that of older students because metacognition develops as childer get older via experience and practice. For example, the traces of metacognitive knowledge shown in kindergarten develop during adolescence and throughout the entire lifespan (see Artelt, Neuenhaus, Lingel, \& Schneider, 2012; Handel, Artelt, \& Weinert, 2013; Schneider, 2008), and metacognitive skills appear at the age of 8 to 10 years, and expand in the years thereafter (Berk, 2003; Veenman et al., 2004). Also, planning, in comparison to both monitoring and evaluation, matures earlier (Veenman \& Spaans, 2005).

\subsection{Association of Self-Efficacy with Metacognition and Academic Achievement}

Self-efficacy, which is a form of motivational self-regulation exerted by competence self-beliefs, is one of the most determinative formulators of various academic outcomes. For example, self-efficacy is a positive predictor of mathematics problem solving and grades (Briggs, 2014; Chen, 2010; Pajares \& Kranzler, 1995; Stevens, Olivarez, Lan, \& Tallent-Runnels, 2004), test achievements for mathematics, languages, and science (Jansen et al., 2015; Lee et al., 2014; Skaalvik, Federici, \& Klassen, 2015).

Self-efficacy beliefs also influence behaviors indirectly (Bandura, 1997; 2002). For example, it affects behavior via its impact on goal intentions (Bandura 2002). As Gollwitzer (1999) mentioned, implementation intentions (or action plans) refer to the translation of goals or intentions into specific actions (How should I behave?) and into the situational circumstances of performance (Where and when should I perform the action?). Therefore, students with high self-efficacy are expected to have stronger intentions, focus on their future behavior and develop success scenarios of their actions, leading to more committed to planning (see Zimmerman \& Schunk, 2008).

Also, academic self-efficacy contributes to the use of complex and effective metacognitive learning strategies (e.g., Lee et al., 2014; Liem, Lau, \& Nie, 2008; Pintrich, 1999; Schunk \& Pajares, 2005). For example, once an action has been taken, individuals with higher self-efficacy, compared to others, believe that they can mobilize the resources required to meet action demands, and exercise control over challenges and over their own 
functioning. Therefore, the individuals with higher self efficacy will put more effort into and pursue their goals longer, selecting more active coping strategies and being more effective in problem-solving, evidenced by the application of effective metacognitive monitoring and regulatory procedures (Lee et al., 2014; Liem et al., 2008; Schunk \& Pajares, 2005).

Efklides (2011) suggests that metacognitive knowledge of self and self-efficacy is positively interrelated. Sang and Wang (2001) found that self-efficacy influences the effect of metacognitive knowledge on students' learning. Further, other researchers document a positive association between self-efficacy and declarative knowledge (e.g., Martocchio \& Hertenstein, 2003). Coutinho (2008) and Tian et al. (2018) suggest that the association between metacognition and academic performance is fully mediated by self-efficacy.

\subsection{Association of Hope with Self-Efficacy, Metacognition and Academic Achievement}

According to Snyder (2000, p. 8), hope is the "sum of perceived capabilities to produce routes to desired goals, along with the perceived motivation to use those routes". The three key components of the Snyder's theory include the conceptualization of a goal, the developed routes to obtain the conceptualized goal (pathways), and the motivation to obtain the conceptualized goal (agency) (Snyder, 2000, p. 10; Snyder \& Lopez, 2006, pp. 188-192). Although they are reciprocal, additive and positively related, agency and pathway are separate constructs, (Chang \& Banks, 2007; Dixton, 2017; Magaletta \& Oliver; 1999; Rand \& Cheavens, 2009; Snyder, Harris, Anderson, Holleran, Irving, Sigmon, Yoshinobu, Gibb, Langelle, \& Harney, 1991).

The majority of the studies support that higher levels of hope are associated with higher academic achievement at all educational levels (Feldman \& Kubota, 2015; Rand et al., 2011; Stephanou, 2012; Snyder et al., 1991; Snyder et al., 1997; Snyder, Shorey, Cheavens, Pulvers, Adams, \& Wiklund, 2002), and with positive academic outcomes (e.g., Buckelew et al., 2008; Ciarrochi et al., 2007; Gallup, 2009; Lopez, Bouwkamp, Edwards, \& Teramoto Pedrotti, 2000), although some studies (e.g., Jackson, Weiss, Lundquist, \& Hooper, 2003; Lackaye \& Margalit, 2008) do not evident the link.

Previous researchers also report that hope is positively associated with positive affect, personal adjustment, self-beliefs and perceived quality of life (see Marques, Gallagher, \& Lopez, 2017). For example, higher hope is linked to higher self-esteem (Gibb, 1990), higher self-worth (Ciarrochi et al., 2007; Curry, Snyder, Cook, Ruby, \& Rehm, 1997; Kwon, 2000; Marques, Pais-Ribeiro, \& Lopez, 2009), stronger problem solving skills (Kwon, 2000), effective problem-solving (Chang, 1998), better handling of stress (Chang, 1998) and stressful life events (Hellman \& Gwinn, 2016; Valle, Huebner, \& Suldo, 2006), and lower depression and anxiety (Ong et al., 2006). Also, hopeful individuals are more optimistic about the future, develop more and longer-term life goals and have higher success expectations (Snyder, Shorey, \& Rand, 2006). In contrast, hope is inversely related to negative affect (Snyder et al., 1997), behavior problems (Valle, Huebner, \& Suldo, 2004), and indicators of psychological distress and school maladjustment (Gilman, Dooley, \& Florell, 2006). Hopeful children, in particular, report better interpersonal relationships and school success regarding attendance, course selection, grade point average, graduation rates, and college going rates (Pedrotti et al., 2008; Stephanou, 2011; see also Marques, Lopez, Fontaine, Coimbra, \& Mitchell, 2015).

Yotsidi, Pagoulatou, Kyriazos and Stalikas (2018), in a review of twenty-three papers, reported that the dispositional hope was a powerful predictor of both academic hope and academic self-efficacy, and that hope indirectly predicted grade point average (GPAs). In the longitudinal study by Gallagher, Marques and Lopez (2017), hope was found to be a formulator factor of academic achievement across all the four years of studies as well as hope uniquely and directly influenced the number of enrolled semesters.

As above mentioned, hope and self-efficacy are motivational factors of achievement behavior. However, hope and self-efficacy focus on competence and control in different ways (Bryant \& Cvengros, 2004; Dixson, Worrell, Olszewski-Kubilius, Subotnik, 2016; Feldman \& Kubota, 2015; Rose \& Robinson, 2007). Specifically, Bandura's (1997) theory suggests that self-efficacy is a stronger predictor of behavior than the actual outcome expectancy. Hope emphasizes equally competence and control belief. More accurately, hope is 'a positive motivational state that is based on an interactively derived sense of successful agency (goal-directed energy) and pathways (planning to meet goals)' (Snyder, Irving, Anderson, 1991, p. 287). Regarding to "outcome expectations in self-efficacy wherein the focus is on the given contingencies, pathways thinking reflects the self-analysis of one's capabilities to produce initial routes to goals, as well as additional routes should the first become impeded' (Snyder, Rand, \& Sigmon, 2005, p. 262) or to identify multiple routes when obstacles arise (Snyder et al., 1991). Moreover, self-efficacy emphasizes the belief that goals can be achieved, while hope agency focuses on the belief that goals will be achieved. In Rand's (2018) words, unlike self-efficacy, hope is a generalized belief and involves the determination to achieve one's goals. 
Past research evident the influential power of hope on academic performance even when controlling for other constructs, such as prior grades (e.g., Gallagher \& Lopez, 2008; Gallagher et al., 2017; Snyder et al., 1991; Snyder, Shorey, et al., 2002) and self-esteem (Snyder, Shorey, et al., 2002). Despite the fact that a very limited number of studies have focused on the role of hope in academic achievement relative to self-efficacy (see Dixton et al., 2016), Feldman and Kubota (2015) found that college students' dispositional hope influenced the formulation of academic self-efficacy, which in turn predicted GPAs.

Hope, in addition, influences goal-directed behavior indirectly through its impact on self-regulation, since high hope individuals are able to handle stressful situations, override their own impulses responses and apply the proper ones toward a pursuit goal, identify and articulate strategies to manage potential barriers and self-regulate energy toward pathways even in front of obstacles and are better problem-solvers (see Alexander \& Onwuegbuzie, 2007; Chang, 1998; Snyder, 2002).

\subsection{Aim and Hypotheses of the Study}

This research aimed to examine (a) students' reported metacognitive knowledge (declarative, procedural, conditional) and metacognitive regulation (planning, monitoring, information management, evaluation) when they are doing school work or homework, and the effect of the reported metacognition on school performance in language and mathematics, (b) the role of hope (both agency thinking, pathway thinking) and general self-efficacy in the reported metacognition, and in its impact on school performance and (c) the effect of hope in the generation of self-efficacy, and on its impact on both metacognition and school performance.

The research hypotheses were the following.

Metacognition will not be fully developed, with declarative knowledge being the favoring component of metacognitive knowledge and evaluation being the less favoring element of metacognitive regulation (Hypothesis 1).

Hope (mainly, agency thinking) will be a positive predictor of general self-efficacy (Hypothesis 2).

Hope will positively predict metacognition (Hypothesis $3 \mathrm{a}$ ). The predictive strength of pathway thinking and agency thinking will vary between metacognitive knowledge and metacognitive regulation (with agency thinking being the most powerful predictor of metacognitive regulation) and within the components of each of them (Hypothesis 3b).

Self-efficacy will be a positive formulator of metacognition, particularly metacognitive regulation (Hypothesis 4a). The predictive power of self-efficacy will differ within the components of metacognitive knowledge and metacognitive regulation (Hypothesis $4 b$ ).

Hope will have a direct effect on metacognition beyond that of general self-efficacy (Hypothesis 5).

Metacognition (both metacognitive knowledge and metacognitive regulation), hope (mainly, agency thinking) and general self-efficacy will be positive influential factors of school performance in both Language and Mathematics (Hypothesis 6a). Self-efficacy will mediate the positive effect of metacognition on school performance (Hypothesis 6b). Hope will enhance the positive effect of both metacognition and general self-efficacy on school performance (Hypothesis $6 \mathrm{c}$ ). The relative strength of predictors will differ between the two school subjects but no specific hypothesis is examined (Hypothesis $6 \mathrm{~d}$ ).

\section{Method}

\subsection{Participants}

One hundred and sixty-five 5th and 6th grade students ( 83 boys, 82 girls), randomly selected from 10 state primary schools of various regions of Greece, participated in the study. Their age ranged from 10 to 12 years with a mean age of 11.5 years $(\mathrm{SD}=.65)$. The students represented various parental socio-economical levels, with the $47,6 \%, 45,1 \%$ and $11,5 \%$ of their parents having completed tertiary education, secondary education and primary education respectively.

Also, the students' teachers (11 female, 9 male) participated in this research whom teaching experience ranged from 3 to 27 years.

\subsection{Measures}

\subsubsection{Metacognition}

The participants' reported metacognitive behaviours in doing school work or home work were assessed through the Junior Metacognitive Awareness Inventory for learners in grades 6 through 9 (Jr. MAI, Version B, Sperling, Howard, Miller, \& Murphy, 2002). This self-report instrument includes two subscales, metacognitive knowledge 
and metacognitive regulation, each of which consists of nine items, with response options ranging from 1 (Never) to 5 (Always). The metacognitive knowledge subscale comprises: Declarative knowledge (e.g., "I know when I understand something"), procedural knowledge (e.g., "I try to use ways of studying that have worked for me before") and conditional knowledge (e.g., "I use different learning strategies depending on the task"). The metacognitive regulation subscale measures five behaviors: Planning (e.g., "I decide what I need to get done before I start a task"), monitoring (e.g., "I ask myself how well I am doing while I am learning something new"), information management (e.g., "I focus on the meaning and significance of new information"), evaluation (e.g., "When I am done with my schoolwork, I ask myself if I learned what I wanted to learn) and debugging which refers to correction of mistakes. For this research, debugging was included in monitoring of metacognition. The Jr. MAI, Version B, is a valid and a reliable research instrument, and it has been widely used (see Kim, Zyromski, Mariani, Lee, \& Carey, 2016; Lai, Zhu, Chen, \& Li, 2015; Ning, 2018; Sperling, Richmond, Ramsay, \& Klapp, 2012). In addition, it is a proper instrument in measuring metacognition in Greek population (see Panaoura \& Philippou, 2003; Stephanou \& Mpiontini, 2017).

In the present study, Cronbach's alphas were $.77, .64$ and .53 for total metacognition, metacognitive regulation and metacognitive knowledge respectively. Also, Cronbach's alphas for the subscales of metacognitive knowledge ranged from .50 for procedural, via .60 for conditional, to .64 for declarative. In a similar way, Cronbach's alpha for the subscales of metacognitive regulation were acceptable: Planning $=.62$, monitoring $=.60$, evaluation $=.65$ and information management $=.68$.

\subsubsection{Hope}

Dispositional hope was examined via the Children's Hope Scale (Snyder, Hoza, et al., 1997), which is designed to measure hope in children aged 7 to 16 . This instrument contains six items: three refer to agency thinking (e.g., "I think I am doing pretty well") and three refer to pathway thinking (e.g., "I can think of many ways to get the things in life that are most important to me"). Responses range from 1 (None of the time) to 5 (All of the time), with higher scores indicating higher levels of dispositional hope. This scale is the most commonly used hope measure, with satisfactory psychometric properties (see Dixson, 2017; Valle et al., 2004; Snyder, Hoza, et al., 1997). The Greek version of the scale is a proper research instrument in examining hope in Greek population (Geitona, 2018; Stephanou, 2011, 2012). In the present study, Cronbach's alphas were .58 for agency thinking and .60 for pathways thinking.

\subsubsection{General Self-Efficacy}

The Greek version (Glynou, Schwarzer, \& Jerusalem, 1994) of the General Self-Efficacy Scale (GSES, Jerusalem \& Schwarzer, 1993; Schwarzer \& Jerusalem, 1995) was used to measure Generic Self-Efficacy. The GSES is a single component self-report tool designed to assess the strength of an individual's belief in his/her own ability to respond to and cope with environmental demands and challenges, such as novel or difficult situations and any associated setbacks or obstacles. It consists of ten items and the response for each item ranges from 1 (Not at all true) to 4 (Exactly true). The higher the score, the greater the sense of self-efficacy. The scale has been translated in 32 languages, has been widely used, and it is a valid and reliable research instrument across various domains and countries (see Luszczynska, Gutiérrez-Doña, \& Schwarzer, 2004; Schwarzer, 2014). In this study, the internal consistency of the scale was acceptable, since Cronabach's alpha was .76.

\subsubsection{School Performance, and Personal Information}

School performance in each of the two school subjects was the average score of the teachers' rating of their students' performance and of the term grade, which was obtained from the school records. The teachers rated each of their students' school performance on a 4-item scale (e.g., "How well does she/he do in Language?"). Responses ranged from 1 (very poorly) to 5 (excellent). Cronbach's alphas were .92 in Language and .95 in Mathematics.

Participant demographic data were obtained via a short set of questions, such as age, gender and grade level. In addition, students and teachers mentioned parents' educational background and teaching experience respectively.

\subsection{Procedures}

Initially, students' parents, teachers and school administration consent were requested and given, and, then, the scales were administered. The participating students and teachers were informed about the aim of this research, and anonymity and confidentiality were guaranteed. Data gathered at the second school term of the total three terms, in order the participants have adequate time to formulate an impression about school performance and metacognition relevant to school work or home work.

All students completed the scales individually in a quiet room outside their classroom, in front of the researchers. 
In a similar way, the questionnaire was administered to the teachers in their own free time in school time, and they rated school performance for each of their students separately.

\section{Results}

\subsection{Metacognitive Knowledge and Metacognitive Regulation}

Descriptive statistics show that the students reported moderate use of metacognitive knowledge and metacognitive regulation while they are doing school work or home work (Table 1). Furthermore, according to the results from the repeated measure ANOVAs, the sub-components of both metacognitive knowledge, $\mathrm{F}(2$, $162)=73.76, \eta^{2}=.63$, and metacognitive regulation, $F(3,161)=26.10, \eta^{2}=.28$, differed from each other in the reported frequency of use. Specifically, in metacognitive knowledge, the presented mean scores on Table 1 and the post hoc pairwise comparison indicate that the students referred to use of conditional knowledge more than declarative knowledge and procedural knowledge which was stressed least. Similarly, with respect to metacognitive regulation, post hoc pairwise comparisons and observation of the mean scores on Table 1 illustrate that the students reported the application of monitoring more than any other component, whereas evaluation was the least used.

The above results in the most confirmed Hypothesis 1.

Table 1. Descriptive statistics for students' reported use of metacognitive knowledge and metacognitive regulation while they are doing school work or home work

\begin{tabular}{lcc}
\hline Components of metacognition & Mean & SD \\
\hline Metacognitive knowledge & & \\
Declarative & 3.82 & .59 \\
Procedural & 3.13 & .86 \\
Conditional & 4.06 & .90 \\
Metacognitive regulation & & \\
Planning & 3.67 & 1.01 \\
Monitoring & 3.81 & .84 \\
Information management & 3.67 & .86 \\
Evaluation & 3.14 & .84 \\
\hline
\end{tabular}

\subsection{Association among Hope, Self-Efficacy and Metacognition}

\subsubsection{Effect of Hope on General Self-Efficacy}

Preliminary analyses showed that students' general self-efficacy (Mean $=3.00, \mathrm{SD}=.51$ ), agency thinking (Mean= 3.87, $\mathrm{SD} .=.62$ ) and pathway thinking (Mean=3.68, $\mathrm{SD}=.67$ ) ranged from moderate to high.

The findings from correlation coefficient analyses showed that the higher the pathway thinking, $r=.42, p<.01$, and the higher the agency thinking, $\mathrm{r}=.29, \mathrm{p}<.01$, were, the higher the general self-efficacy was. Furthermore, the results from a regression analysis with the two components of hope as predictors revealed that hope explained $16 \%$ of the variance of general self-efficacy, $\mathrm{F}(2,162)=35.60, \mathrm{p}<.01$; pathway thinking contributed the most, beta $=.42, \mathrm{t}=5.90, \mathrm{p}<.01$; yet agency thinking, beta $=.28, \mathrm{t}=3.81, \mathrm{p}<.01$, had a significant positive contribution to self efficacy. These findings partially confirmed Hypothesis 2 .

3.2.2 Effects of hope and general self-efficacy on metacognition, and the role of hope in the impact of general self-efficacy on metacognition

To examine the role of hope (pathway thinking and agency thinking) and self-efficacy in metacognition, and the effect of hope in the generation of the impact of self-efficacy on metacognition, a series of hierarchical regression analyses were conducted, with self-efficacy (entered into first step of the analysis), and agency thinking and pathway thinking (entered simultaneously into second step of the analysis) as the predictors. Separate analyses were performed for total metacognitive knowledge, total metacognitive regulation and each of the seven components of metacognition.

The findings regarding total metacognitive knowledge revealed that hope and self-efficacy, together, had positive effect on it, $\mathrm{R}^{2}=.49, \mathrm{~F}(2,162)=17.76, \mathrm{p}<.01$, and that agency thinking and pathway thinking, in combination, had direct effect on metacognitive knowledge beyond that of self-efficacy, $\mathrm{R}^{2} \mathrm{ch}=.24, \mathrm{~F}(3,161)=17.76, \mathrm{p}<.01$. In a similar way, hope and self-efficacy, together, proved positive influential factor of total metacognitive 
regulation, $\mathrm{R}^{2}=.18, \mathrm{~F}(2,162)=18.64, \mathrm{p}<.01$, while agency thinking and pathway thinking, in combination, had direct effect on it, beyond that of self-efficacy, $\mathrm{R}^{2} \mathrm{ch}=.20, \mathrm{~F}(3,161)=13.93, \mathrm{p}<.01$.

The results (Table 2) regarding the components of metacognition showed that higher self-efficacy and higher hope was correlated with higher reported metacognitive knowledge (mainly declarative) and metacognitive regulation (predominately, monitoring). More specifically, the results from these analyses revealed the following.

Concerning reported declarative knowledge, the predictive model was found to be statistically significant, explaining $27 \%$ of the variance, $\mathrm{F}(3,161)=16.46, \mathrm{p}<.01$. Further, agency thinking and pathway thinking, together, enhanced the effect of self-efficacy on it, $\mathrm{R}^{2} \mathrm{ch}=.05$. Self-efficacy, however, proved unique positive contributor, beta $=.46, \mathrm{t}=6.10, \mathrm{p}<.01$.

Conditional knowledge was found to be influenced by the two sets of predictors, in combination, $\mathrm{R}^{2}=.15, \mathrm{~F}(3$, $161)=8.11, \mathrm{p}<.01$, and uniquely by the two types of hope, together, $\mathrm{R}^{2} \mathrm{ch}=.03$. However, the general self-efficacy proved the solo positive contributor of it, beta $=.34, t=4.21, \mathrm{p}<.01$.

Hope and self-efficacy, together, influenced planning of metacognitive regulation, $\mathrm{R}^{2}=.12, \mathrm{~F}(3,161)=7.86, \mathrm{p}$ $<.01$, but agency thinking and pathway thinking, in combination, had no direct effect on it beyond that of self-efficacy. Self-efficacy positively contributed into planning, beta $=.34, t=4.20, p<.01$.

In monitoring of metacognitive regulation, the predictive model was significant, accounting $19 \%$ of its variability, $\mathrm{F}(3,161)=11.56, \mathrm{p}<.01$, and pathway thinking and agency thinking, together, enhanced the effect of general self-efficacy on it, $\mathrm{R}^{2} \mathrm{ch}=.04$. In addition, the students who were high in both general self-efficacy, beta $=.40, \mathrm{t}=5.08, \mathrm{p}<.01$, and agency thinking, beta $=.15, \mathrm{t}=2.75, \mathrm{p}<.01$, were more likely to report use of monitoring, while pathway thinking had no direct effect on monitoring.

In information management, hope and self-efficacy, in combination, positively predicted its generation, explaining $15 \%$ of the variance, $\mathrm{F}(3,161)=6.78, \mathrm{p}<.01$, the two types of hope thinking, together, had direct and positive effect on it, beyond that of self-efficacy, $\mathrm{R}^{2} \mathrm{ch}=.09$, but only pathway thinking had unique impact on it, beta $=.28, \mathrm{t}=3.04, \mathrm{p}<.01$.

Unexpectantly, while general self-efficacy and hope, in combination accounted for a significant and positive variability in evaluation of metacognition, $\mathrm{R}^{2}=.08, \mathrm{~F}(3,161)=5.80, \mathrm{p}<.05$, none of them had direct effect. Also, hope and self-efficacy had no impact on procedural knowledge uniquely or in combination.

The above findings partly confirmed Hypotheses $3 \mathrm{~b}$ and $4 \mathrm{a}$, while they totally confirmed Hypothesis $3 \mathrm{a}, 4 \mathrm{~b}$ and 5. 
Table 2. Results from hierarchical regression analyses for the role of self-efficacy and hope (agency thinking, pathway thinking) in the components of both metacognitive knowledge and metacognitive regulation, and for the role of hope in the impact of self-efficacy on the same components of metacognition

\begin{tabular}{|c|c|c|c|c|c|c|c|}
\hline Predictors & Steps & $\mathrm{R}^{2}$ & F & $\mathrm{R}^{2} \mathrm{ch}$ & Fch & beta & $\mathrm{t}$ \\
\hline & & \multicolumn{6}{|c|}{ Declarative knowledge } \\
\hline Self-efficacy & $1^{\mathrm{o}}$ & .22 & $48.49^{* *}$ & .22 & $48.49 * *$ & .46 & $6.10 * *$ \\
\hline Pathway thinking & $2^{\circ}$ & & & & & .07 & .37 \\
\hline \multirow[t]{3}{*}{ Agency thinking } & & & & & & -.07 & .34 \\
\hline & & .27 & $16.46^{* *}$ & .05 & $4.70^{* *}$ & & \\
\hline & & \multicolumn{6}{|c|}{ Procedural knowledge } \\
\hline Self-efficacy & $1^{\mathrm{o}}$ & .019 & 3.16 & .019 & 3.16 & .19 & 2.20 \\
\hline Pathway thinking & $2^{\circ}$ & & & & & -.14 & -1.40 \\
\hline \multirow[t]{3}{*}{ Agency thinking } & & & & & & .00 & .02 \\
\hline & & .035 & 1.95 & .00 & .29 & & \\
\hline & & \multicolumn{6}{|c|}{ Conditional knowledge } \\
\hline Self-efficacy & $1^{\mathrm{o}}$ & .12 & $23.85^{* *}$ & .12 & $23.85^{* * *}$ & .34 & $4.21 * *$ \\
\hline Pathway thinking & $2^{\circ}$ & & & & & .07 & .77 \\
\hline \multirow[t]{3}{*}{ Agency thinking } & & & & & & -.05 & -.58 \\
\hline & & .15 & $8.11 * *$ & .03 & $3.99 *$ & & \\
\hline & \multicolumn{7}{|c|}{ Planning } \\
\hline Self-efficacy & $1^{\mathrm{o}}$ & .12 & $23.19^{* *}$ & .12 & $23.19 * *$ & .34 & $4.20 * *$ \\
\hline Pathway thinking & $2^{\circ}$ & & & & & .05 & .58 \\
\hline \multirow[t]{3}{*}{ Agency thinking } & & & & & & -.06 & -.72 \\
\hline & & .12 & $7.86^{* *}$ & .02 & 2.39 & & \\
\hline & \multicolumn{7}{|c|}{ Monitoring } \\
\hline Self-efficacy & $1^{\mathrm{o}}$ & .16 & $32.87^{* *}$ & .16 & $32.87 * *$ & .40 & $5.08 * *$ \\
\hline Pathway thinking & $2^{\circ}$ & & & & & .09 & 1.02 \\
\hline \multirow[t]{3}{*}{ Agency thinking } & & & & & & .15 & $2 . .75^{*}$ \\
\hline & & .19 & $11.56^{* *}$ & .04 & $3.83^{*}$ & & \\
\hline & \multicolumn{7}{|c|}{ Information management } \\
\hline Self-efficacy & $1^{\mathrm{o}}$ & .10 & $11.41^{* *}$ & .10 & $11.41 * *$ & .15 & 1.85 \\
\hline Pathway thinking & $2^{\circ}$ & & & & & .28 & $3.04 * *$ \\
\hline \multirow[t]{3}{*}{ Agency thinking } & & & & & & -.08 & -1.00 \\
\hline & & .15 & $6.78 * *$ & .06 & $8.32 * *$ & & \\
\hline & \multicolumn{7}{|c|}{ Evaluation } \\
\hline Self-efficacy & $1^{\mathrm{o}}$ & .06 & $8.50 * *$ & .06 & $8.50 * *$ & .14 & 1.65 \\
\hline Pathway thinking & $2^{\circ}$ & & & & & -.06 & -.19 \\
\hline \multirow[t]{2}{*}{ Agency thinking } & & & & & & -.13 & -1.48 \\
\hline & & .08 & $5.82 *$ & .018 & 2.00 & & \\
\hline
\end{tabular}

Note: $*: \mathrm{p}<.05, * *: \mathrm{p}<.01$, while the rest of the F-, Fch- and t- values, $\mathrm{p}>.05$. 


\subsection{The Role of Hope, Self-Efficacy and Metacognition in School Performance in Language and Mathematics}

Two separate hierarchical regression analyses were performed to examine (a) the role of hope, self-efficacy and metacognition in the formulation of students' school performance in language and mathematics, (b) the effect of self-efficacy on the impact of metacognition on the same performances and (c) the role of hope in the impact of self-efficacy and metacognition on the performances. Metacognition (metacognitive knowledge, metacognitive regulation), self-efficacy and hope (pathway thinking, agency thinking) were entered in the first, second and third step of analysis, respectively. The findings revealed that the three sets of predictors had complementary and positive effects on school performance but their relative power in influencing it varied between mathematics and language and within each school subject.

The results regarding language were the following: (a) the three constructs, in combination, positively influenced school performance, $\mathrm{R}^{2}=.32, \mathrm{~F}(10,154)=5.79, \mathrm{p}<.01$, (b) general self-efficacy had indirect impact on performance through metacognition, $\mathrm{R}^{2} \mathrm{ch}=.025, \mathrm{Fch}(7,157)=1,00, \mathrm{p}>.05$, (c) hope improved the effect of self-efficacy and metacognition on performance, revealing its direct effect on it, $R^{2} \mathrm{ch}=.22, F(8,156)=1.75, p$ $<.01$, and (d) agency thinking, compared to other predictors, was the most powerful positive formulator of school performance, beta $=.31, \mathrm{t}=3.89, \mathrm{p}<.01$, followed by procedural knowledge, beta $=.25, \mathrm{t}=3.42, \mathrm{p}<.01$, evaluation, beta $=.18, \mathrm{t}=2.10, \mathrm{p}<.05$, monitoring, beta $=.16, \mathrm{t}=1.95, \mathrm{p}<.05$, and declarative knowledge, beta $=.11, \mathrm{t}=1.90, \mathrm{p}<.05$, while information management was a negative contributor of it, beta $=-.29, \mathrm{t}=-4.14$, $\mathrm{p}<.01$, and (d) the rest of the variables did not influenced the formulation of performance uniquely.

The results regarding mathematics revealed that (a) hope, self-efficacy and metacognition, as a group, explained a moderate amount of the variance of school performance, $\mathrm{R}^{2}=.20, \mathrm{~F}(10,154)=3.80, \mathrm{p}<.01$, (b) general self-efficacy had direct effect on students' performance, beyond that of metacognition, $\mathrm{R}^{2} \mathrm{ch}=.08, \mathrm{Fch}(7,157)=$ $8.20, \mathrm{p}<.01$, (c) hope (pathway thinking and agency thinking, together) accounted uniquely in school performance, beyond the impact of self-efficacy and metacognition, $\mathrm{R}^{2} \mathrm{ch}=.06, \mathrm{~F}(8,156)=4.00, \mathrm{p}<.01$, and (d) agency thinking was the most powerful positive predictor of performance, beta $=.28, \mathrm{t}=3.18, \mathrm{p}<.01$, followed by declarative knowledge, beta $=.23, \mathrm{t}=3.00, \mathrm{p}<.01$, self-efficacy, beta $=.19, \mathrm{t}=2.60, \mathrm{p}<.01$, monitoring, beta $=.14, \mathrm{t}=2.10, \mathrm{p}<.01$, and planning, beta $=.11, \mathrm{t}=1.98, \mathrm{p}<.05$, while information management was a negative contributor of performance, beta $=-.28, \mathrm{t}=-3.40, \mathrm{p}<.001$.

The above findings partly, in the most and totally confirmed Hypotheses $6 \mathrm{~b}, 6 \mathrm{a}$ and both $6 \mathrm{c}$ and $6 \mathrm{~d}$ respectively.

\section{Discussion}

The present study examined the role of metacognition and motivation- function factors of general self-efficacy and hope in the formulation of school performance in mathematics and language in elementary school. This research also investigated the relationships shared between hope, general self-efficacy and metacognition in regards the same school performances.

The findings from the present investigation confirmed some results from previous studies and also revealed new relationships among the examined variables, leading to significant conclusions and implications for educational practice and achievement motivation research. The results from this research provide evidence for the relationship shared among metacognition, hope and self-efficacy and the way in which these constructs operate in predicting student achievement. The hypothesized sequential mediation effects of hope and self-efficacy between metacognition and school performance were in the most supported in this study.

\subsection{Metacognition}

The results regarding metacognition revealed that students' self-report metacognitive knowledge and metacognitive regulation in doing school work or homework were at moderate level, complimenting the notion that metacognitive knowledge develops beyond elementary school (Artelt et al., 2012; Schneider, 2008), and regulation of cognition develops slowly and might not be completely operative even in adults (Lai, 2011; Van der Stel \& Veenman, 2014; Veenman \& Spaans, 2005; Weil, Fleming, Dumontheil, Kilford, Weil, Rees, \& Blakemore, 2013). The findings, in addition, confirming the literature (e.g., Schneider \& Lockl, 2002; Veenman, 2011; Veenman et al., 2006) about the variability of the development of the components of both constructs, and in consistency with past researchers (e.g., Gourgey, 2010; Handel et al., 2013; Martini \& Shore, 2008; Stephanou \& Mpiontini, 2017), supported the least use of both procedural knowledge and evaluation of metacognitive regulation. The low use of evaluation might be also an evidence that students had not been trained trough the school curriculum to evaluate their own achievement behavior, although self-feedback is essential component of effective learning and transfer (Bransford, Brown, \& Cocking, 2000; Schraw, 1998). On the other hand, in contrast to speculation that planning matures earlier than monitoring and evaluation (Veenman, 2011) 
and to previous studies (see Stephanou \& Mpiontini, 2017), students most frequently referred to monitoring.

The most use of conditional knowledge might be partly explained by the participants' beliefs in their own ability in handling effectively the demands of the familiar tasks of mathematics and language, since this specific knowledge is associated with metacognitive experiences (see Flavell, 1979; Efklides, 2008; Harris et al., 2009).

Moreover, the moderate level of both metacognitive regulation and metacognitive knowledge might result from a lack of emphasis on metacognition in most classrooms (see Eccles \& Roeser, 2011; Metallidou, 2009), although achieving awareness of one's own cognition and how to regulate it at the primary years is a major factor in school functioning (Goswami, 2015; Schneider \& Artelt, 2010). The moderate level of metacognition could be also associated with the self-report measure of Jr.MAI. Literature suggest that learners may not be consciously aware of their cognition, although they apply metacognitive strategies (Lai, 2011; Schraw \& Moshman, 1995). More research needs to specify such issues.

Metacognition, supporting previous studies (e.g., Callan \& Cleary, 2018; Harris, 2015; Zohar \& Peled, 2008), played an important positive role in school performance in mathematics and language. The pattern of the effect of metacognition on academic performance, however, is complicated, evidencing, on one hand, the meditative role of self-efficacy and hope, and, on the other hand, the determinative role of its most often used components. The significant effect of conditional knowledge and the non-significant effect of procedural knowledge on mathematics could be due to the fact that school does not emphasize on how transforming the mastery/declarative knowledge into application in the complex task of mathematics.

The unexpectable negative role of information management in school performance is a puzzle. It seems that the participants thought that-- or they did- knew the surroundings and where they were with regard to their goals but they did not apply that knowledge to succeed, probably, due to inadequate skills to do it. Students can be trained to do so, as previous empirical research in metacognition training has addressed (see Csíkos \& Steklács, 2010; Schneider \& Artelt, 2010).

\subsection{General Self-Efficacy}

Self-efficacy, in consistency to its crucial role in self-regulation (Boekaerts, 1997; Zimmerman, 2000, 2008) and self-regulated learning (Boekaerts \& Corno, 2005; Caprara et al., 2008; Moores, Chang, Smith, 2006; Panadero, 2017; Zimmerman \& Schunk, 2011), contributed in metacognitive knowledge and, mainly, metacognitive regulation. Also, confirming past researchers (e.g., Caprara, Vecchione, Alessandri, Gerbino, \& Barbaranelli, 2011; Stevens et al., 2004), the higher the self-efficacy was the higher the school performance was. Furthermore, general self-efficacy proved a mediator factor of the effect of metacognition on school performance in both language and mathematics. Taking in consideration that language and mathematics are high complex tasks, this specific result, at a very first glance, seems to be against previous findings (e.g., Gist \& Mitchell, 1992) that support as the task complexity and the cognitive demands increase, the role of metacognition in performance increases. It is possible that the estimation of the average performance, and not its specific tasks, in both school subjects moderates the relationship between metacognition and performance. These results are also in agreement to theories of self-regulated learning that suggest that knowledge about relevant metacognitive strategies improves comprehension only when learners are also motivated to use these strategies (Maier \& Richter, 2014).

The smaller effect of self-efficacy on metacognition and school performance (no unique contribution in language performance), comparing to other studies (e.g., Petosa, Suminski, \& Hortz, 2003) that have shown higher effect of domain-specific self-efficacy on those variable, was probably because of the generality of the self-efficacy construct used in the present study.

\subsection{Hope}

High hope was found to predict school performance, confirming other studies (Snyder et al, 2002; Stephanou, 2012; see also Feldman \& Kubota, 2015; Marques et al., 2017; Yotsidi et al., 2018) as well as it proved predictor of metacognition. Furthermore, the present results, supporting previous research studies (e.g., Bryant \& Cvengros, 2004; Ben-Naim, Laslo-Roth, Einav, Biran, \& Margalit, 2017; Dixton et al., 2016; Peterson, Gerhardt, \& Rode, 2006; Tennen, Affleck, \& Tennen, 2002), suggest that, while the influence of self-efficacy and hope are agentically mediated through one another, they operating as distinct constructs. As expected, students with higher hope were more likely than their lower-hope counterparts to report- and probably to engage in successful metacognitive behavior. Additionally, the results demonstrated that hopeful thinking had a direct effect on the reported metacognition beyond that of self-efficacy which, in turn, predicted metacognition.

The results also showed that hope served as a better indicator variable for the system of competence and control, hiding caution for research studies which identify self-efficacy as the better predictor variable when investigating 
motivational constructs. This finding is similar to study by Levi, Einav, Ziv, Raskind and Margalit (2014) which showed the direct effect of hope on grade expectations, which, in turn, predicted academic achievement. Moreover, the findings of the study imply that perceiving oneself to be efficacious does not, in itself, promote student achievement.

The present findings suggest that hope is associated with crucial goal-relevant behaviors, it has unique theoretical explanatory power (see Luthans \& Jensen, 2002; Marques et al., 2017; Rand, 2018), and, consequently, efforts to increase hopeful thought may be significant in helping students to move toward important school outcomes.

Another important finding revealed that, as pathway thinking and agency thought were separated each other, the predictive power of hope weakens and the role of self-efficacy becomes more important in both metacognition and school performance. This finding is in contrast to Chang and Banks (2007) and Campbell and Kwon (2001), who suggest the investigation of the two interrelated components (agency and pathways) of academic hope separately into the model of competence and control beliefs, while it supports the notion that although hope composed of two factors, it is "a positive motivational state that is based on an interactively derived sense of successful (a) agency (goal directed energy) and (b) pathways (planning to meet goals)" (Snyder et al., 1991, p. 287). For example, the generation of routes or strategies increases one's sense of agency which, in turn, enhances the strategic planning. Also, the participants' age might be associated with this specific finding. The fifth and sixth grade students' hope might be not yet divided into distinct pathway thought and agency thought.

The valence of the prediction of the two elements of hope varied between and within the components of metacognition as well as it varied between and within mathematics and language, in favoring agency thinking. This finding might be expected since, agency is the motivating component of hope (Snyder \& Lopez, 2009), and individuals high in agency are determined, motivated and energy directed towards obtaining results (Creamer, O'Donnell, Carbon, Lewis, Densley, McFarlane, 2009). The high importance of mathematics and language for the participants might partly explain this result because agency is more strongly emphasized when objectives of considerable value to the individual exist (Snyder \& Lopez, 2005, 2007). However, pathway thinking, and not agency thinking, uniquely influenced information management, in consistency with the Snyder's argument that high hope individuals do not react in the same way to barriers as low hope individuals, instead they view barriers as challenges to overcome and use their pathway thoughts to plan an alternative route to their goals (Snyder, 1994 as cited in Snyder, 2000 p. 10).

\subsection{Limitations, Practical Implications, Future Research}

There are some limitations in this investigation which could be considered fruitful research lines in the future. First, self-efficacy was general construct. Stronger relations were found for specific domain-efficacy and academic performance (Petosa, Suminski, \& Hortz, 2003), while other studies revealed that general self-efficacy and performance was mediated by task-specific self-efficacy (Chen, Gully, \& Eden, 2004; Yeo \& Neal, 2006). Similarly, this study examined dispositional hope but an individual may have hope for a specific goal which initially is based on her/his trait hope level (Edwards, Rand, Lopez, \& Snyder, 2007; Snyder, 1994). A necessary step for future research is the examination of these general constructs jointly with domain-specific cognitions, as previous researchers suggest (see Barahona, García1, Sánchez-García1, Barba1, \& Galindo-Villardón, 2018; Edwards et al., 2007; Luszczynska, Scholz, \& Schwarzer, 2005; Marqueset al., 2017).

Second, data were gathered from a sample of 5 th and 6th grade students. The findings might be unique to this age and to demands of the primary educational level. Therefore, it is interesting to explore these variables in different educational levels and other stages of life. Third, self-report measures were used, which could have produced common method bias variance. Future studies need to include objective measures. Additionally, following previous investigations, fairly simple measure of metacognition was applied. The complexity of this concept, involving knowledge and experience, may warrant further research into its measurement.

Despite these limitations, this study contributes to and expands the extant literature by highlighting the underlying mechanism by which metacognition contributes to school performance.

In recognition of the importance of metacognition, the present research examined its role in performance in two major school subjects. Metacognition was found to be significant and positive predictor of school performance, although some of its components had only indirect effect. As Efklides (2014) supports, metacognition is socially shared and constructed. More precisely, the adults' role is crucial in supporting children's metacognitive knowledge, especially procedural (Robson, 2016), and their metacognitive regulation (Mevarech \& Fridkin, 2006) via training programs, prompts and scaffolds (see Azevedo, 2005; Dignath \& Buttner, 2008; Schneider, 2010; Stark \& Krause, 2009). 
This research also aimed at identifying how self-efficacy, hope and metacognition are interrelated, and, in turn, how they influence academic achievement. The results revealed that knowledge about- and regulation ofrelevant metacognitive strategies improves school performance only when learners are also high-efficacious and have high hope thought. Further, this study supports the notion that hope (mainly, agency thinking) has unique theoretical explanatory power in academic achievement beyond that of metacognition and self-efficacy.

It seems that hope had a beneficial important role in the process of pursuing a goal since being successful in the academic tasks requires a combination of planning and motivation (Feldman \& Kubota, 2015). Hence, in mathematics and language teaching, teachers should increase students' hope that lead them to apply metacognition more actively and effectively, and, in, turn to succeed. Hope-based intervention could be based on previous effective relevant programs (e.g., Marques, Lopez, \& Pais-Ribeiro, 2011).

General self-efficacy proved a positive contributor into metacognition and school performance, evidencing its high importance in explanation of student' motivation and behavior across different task domains. However, as Bandura has noted (1997), generic self-efficacy and domain self-efficacy are not entirely independent. To design training programs that could enhance students' general self-efficacy, along with their specific-domain efficacy, is required.

Conclusively, this research addressed a gap, but there is definitely more research needed to fully understand the role of self-efficacy, hope, and metacognition predictability of student school performance.

\section{References}

American Psychological Association. (1972). Ethical standards of psychologists. Washington, DC: American Psychological Association.

Anderson, C. A., Gentile, D. A., \& Buckley, K. E. (2007). Violent video game effects on children and adolescents: Theory, research and public policy. https://doi.org/10.1093/acprof:oso/9780195309836.001.0001

Beck, C. A. J., \& Sales, B. D. (2001). Family mediation: Facts, myths, and future prospects (pp. 100-102). Washington, DC: American Psychological Association. https://doi.org/10.1037/10401-000

Bernstein, T. M. (1965). The careful writer: A modern guide to English usage (2nd ed.). New York, NY: Atheneum.

Bjork, R. A. (1989). Retrieval inhibition as an adaptive mechanism in human memory. In H. L. Roediger III, \& F. I. M. Craik (Eds.). Varieties of memory \& consciousness (pp. 309-330). Hillsdale, NJ: Erlbaum.

Cress, C. M. (2009). Curricular strategies for student success and engaged learning [PowerPoint slides]. Retrieved from http://www.vtcampuscompact.org/2009/TCL_post/presenter_powerpoints /Christine\%20Cress\%20-\%20Curricular\%20Strategies.ppt

Driedger, S. D. (1998, April 20). After divorce. Maclean's, 111(16), 38-43.

Gibbs, J. T., \& Huang, L. N. (Eds.). (1991). Children of color: Psychological interventions with minority youth. San Francisco, CA: Jossey-Bass.

Gilbert, D. G., McClernon, J. F., Rabinovich, N. E., Sugai, C., Plath, L. C., Asgaard, G., ... Botros, N. (2004). Effects of quitting smoking on EEG activation and attention last for more than 31 days and are more severe with stress, dependence, DRD2 A 1 allele, and depressive traits. Nicotine and Tobacco Research, 6, 249-267. https://doi.org/10.1 080/1462220041 0001676305

Goleman, D. (2009). What makes a leader? In D. Demers (Ed.), AHSC 230: Interpersonal communication and relationships (pp. 47-56). Montreal, Canada: Concordia University Bookstore. (Reprinted from Harvard Business Review, 76(6), pp. 93-102, 1998).

Guignon, C. B. (1998). Existentialism. In E. Craig (Ed.). Routledge encyclopedia of philosophy (Vol. 3, pp. 493-502). London, England: Routledge.

Healey, D. (2005). Attention deficit/hyperactivity disorder and creativity: An investigation into their relationship (Unpublished doctoral dissertation). University of Canterbury, Christchurch, New Zealand.

Herculano-Houzel, S., Collins, C. E., Wong, P., Kaas, J. H., \& Lent, R. (2008). The basic nonuniformity of the cerebral cortex. Proceedings of the National Academy of Sciences, 105, 12593-12598. https://doi.org/10.1073/pnas.0805417105

Klimoski, R., \& Palmer, S. (1993). The ADA and the hiring process in organizations. Consulting Psychology Journal: Practice and Research, 45(2), 10-36. https://doi.org/10.1037/1061-4087.45.2.10 
Kubrick, S. (Director). (1980). The Shining [Motion picture]. United States: Warner Brothers.

Liu, S. (2005, May). Defending against business crises with the help of intelligent agent based early warning solutions. Paper presented at the Seventh International Conference on Enterprise Information Systems, Miami, FL. Abstract retrieved from http://www.iceis.org/iceis2005/abstracts_2005.htm

MacIntyre, L. (Reporter). (2002, January 23). Scandal of the Century [Television series episode]. In H. Cashore (Producer), The fifth estate. Toronto, Canada: Canadian Broadcasting Corporation.

McLuhan, M. (1970a). Culture is our business. New York, NY: McGraw-Hill.

McLuhan, M. (1970b). From cliche to archetype. New York, NY: Viking Press.

Mellers, B. A. (2000). Choice and the relative pleasure of consequences. Psychological Bulletin, 126, 910-924. https://doi.org/10.1037/0033-2909.126.6.910

Postman, N. (1979). Teaching as a conserving activity. New York, NY: Delacorte Press.

Postman, N. (1985). Amusing ourselves to death: Public discourse in the age of show business. New York, NY: Viking.

Semenak, S. (1995, December 28). Feeling right at home: Government residence eschews traditional rules. Montreal Gazette, p. A4.

Strong, E. K. Jr., \& Uhrbrock, R. S. (1923). Bibliography on job analysis. In L. Outhwaite (Series Ed.), Personnel Research Series: Vol. 1. Job analysis and the curriculum (pp. 140-146). https://doi.org/10.1037/10762-000

Abdellah, R. (2015). Metacognitive awareness and its relation to academic achievement and teaching performance of pre-service female teachers in Ajman. University in UAE. Procedia - Social and Behavioral Sciences 174, 560 -567.

Adler, I., Zion, M., \& Mevarech, Z. R. (2016). The effect of explicit environmentally oriented metacognitive guidance and peer collaboration on students' expressions of environmental literacy. Journal of Research in Science Teaching, 53(4), 620-663. (000119147)

Alexander, P. A. (2008). Why This and Why Now? Introduction to the Special Issue on Metacognition, Self-Regulation, and Self-Regulated Learning. Educational Psychology Review, 20(4), 369-372. http://doi.org/10.1007/s10648-008-9089-0

Alexander, E. S., \& Onwuegbuzie, A. J. (2007). Academic procrastination and the role of hope as a coping $\begin{array}{llll}\text { strategy. Personality and Individual } & \text { Differences, } & 42(7), & \text { 1301-1310. }\end{array}$ http://dx.doi.org/10.1016/j.paid.2006.10.008

Antonietti, A., Ignazi, S., \& Perego, P. (2000). Metacognitive knowledge about problem-solving methods. British Journal of Educational Psychology, 70(1), 1-16.

Artelt, C., Naumann, J., \& Schneider, W. (2010). Lesemotivation und Lernstrategien. In E. Klieme, C. Artelt, J. Hartig, N. Jude, O. Köller, M. Prenzel, W. Schneider, \& P. Stanat (Eds.), PISA 2009. Bilanz nach einem Jahrzehnt (pp. 73-112). Münster, Germany: Waxmann.

Artelt, C., Neuenhaus, N., Lingel, K., \& Schneider, W. (2012). Entwicklung und wechselseitige: Effekte von metakognitiven und bereichsspezifischen. Wissenskomponenten in der Sekundarstufe. Psychologische Rundschau, 63, 18-25.

Artelt, C., Schiefele, U., \& Schneider, W. (2001). Predictors of reading literacy. European Journal of Psychology of Education, 16, 363-383.

Bakracevic-Vukman, K., \& Licardo, M (2010). How cognitive, metacognitive, motivational and emotional self-regulation influence school performance in adolescence and early adulthood. Educational Studies, 36(3), 259-268.

Bandura, A. (1997). Self-efficacy: The exercise of self-control. New York: Freeman.

Barahona, G. V., García1, N. G., Sánchez-García1, A. B., Barba1, M. S., \& Galindo-Villardón1, M. P. (2018). Seven methods to determine the dimensionality of tests: Application to the General Self-Efficacy Scale in twenty-six countries. Psicothema, 30(4), 442-448

Benbenutty, H., Cleary, T. J., \& Kitsantas, A. (2014). Applications of Self-Regulated Learning across Diverse Disciplines. Charlotte, NC: Information Age Publishing, Inc. 
Ben-Naim, S., Laslo-Roth, R., Einav, M., Biran, H., \& Margalit, M. (2017). Academic self-efficacy, sense of coherence, hope and tiredness among college students with learning disabilities. European Journal of Special Needs Education, 32, 18-34. http://dx.doi.org/ 10.1080/08856257.2016.1254973.

Berk, L. E. (2003). Child Development (6th ed.). Boston: Allyn and Bacon.

Boekaerts, M. (1997). Self-regulated learning: A new concept embraced by researchers, policy makers, educators, teachers, and students. Learning and Instruction, 7, 161-186.

Boekaerts, M., \& Corno, L. (2005). Self-regulation in the classroom: A perspective on assessment and intervention. Applied Psychology: An International Review, 54(2), 199-231.

Bransford, J., Brown, A. L., \& Cocking, R. R. (2000). How people learn: Brain, mind, experience, and school. Washington DC: National Academy Press.

Briggs, C. (2014). Mathematics: Self-Efficacy, Identity, and Achievement Among African American Males from the High School Longitudinal Study. Ed.D. Alabama State University, Montgomery, AL.

Brown, A. L. (1978). Knowing when, where, and how to remember: A problem of metacognition. Advances in Instructional Psychology, 1, 77-165.

Brown, A. L. (1987). Metacognition, executive control, self-regulation, and other more mysterious mechanisms. In F. E. Weinert \& R. Kluwe (Eds.), Metacognition, motivation, and understanding (pp. 65-116). Hillsdate: L. Erlbaum Associates.

Bruning, R. H., Schraw, G. J., \& Norby, M. M. (2011). Cognitive psychology and instruction (5th ed.). Boston, MA: Pearson.

Bryant, F. B., \& Cvengros, J. A., (2004). Distinguishing hope and optimism: Two sides of a coin, or two separate coins? Journal of Social and Clinical Psychology, 23(2), 273-302.

Buckelew, S. P., Crittendon, R. S., Butkovic, J. D., Price, K.B., \& Hurst, M. (2008). Hope as a predictor of academic performance. Psychological Reports, 103: 411-414.

Callan, G. L., \& Cleary, T. J. (2018). Multidimensional assessment of self-regulated learning with middle school math students. School Psychology Quartely, 33, 103-111. 10.1037/spq0000198

Campbell, D. G., \& Kwon, P. (2001). Domain-specific hope and personal style: Toward an integrative understanding of dysphoria. Journal of Social and Clinical Psychology, 20(4), 498-520.

Caprara, G. V., Fida, R., Vecchione, M., Del Bove, G., Vecchio, G. M., Barbaranelli, C., \& Bandura, A. (2008). Longitudinal analysis of the role of perceived self-efficacy for self-regulated learning in academic continuance and achievement. Journal of Educational Psychology, 100, 525-534.

Caprara, G. V., Vecchione, M., Alessandri, G., Gerbino, M., \& Barbaranelli, C. (2011). The contribution of personality traits and self-efficacy beliefs to academic achievement: A longitudinal study. British Journal of Educational Psychology, 81, 78-96. http://dx.doi.org/10.1348/2044-8279.002004.

Carr, M. (2010). The importance of metacognition for conceptual change and strategy use in mathematics. In H. S. Waters \& W. Schneider (Eds), Metacognition, Strategy Use, \& Instruction (pp. 176-197). London: The Guildford Press.

Cera, R., Mancini, M., \& Antionietti, A. (2013). Relationships between Metacognition, Self-efficacy and Self-regulation in Learning. Journal of Educational, Cultural and Psychological Studies, 7, 115 - 141. doi:10.7358/ecps-2013-007-cera

Chang, E. C. (1998). Hope, problem-solving ability, and coping in a college student population: Some implications for theory and practice. Journal of Clinical Psychology, 54, 953-962. doi:10.1002/(SICI)1097-4679(199811)54:7<953: AID-JCLP9>3.0.CO;2-F

Chang, E. C. \& Banks, K. H. (2007). The color and texture of hope: Some preliminary findings and implications for hope theory and counseling among diverse racial/ethnic groups. Cultural Diversity \& Ethnic Minority Psychology, 13, 94-103. doi:10.1037/1099-9809.13.2.94

Chen, Y. C. (2010). Sources of Mathematics Self-Efficacy and Predictors of Mathematics Achievement Among Seventh- and Eighth-Grade Taiwanese Students. Ph.D. University of Kentucky, Lexington, KY.

Chen, G., Gully, S. M., \& Eden, D. (2004). General self-efficacy and self-esteem: Toward theoretical and empirical distinction between correlated self-evaluations. Journal of Organizational Behavior, 25, 375- 395 
Chonan, H., \& Sawa, T. (2009). A Perspective on the Role of Metacognition in Reading by Students with Hearing Impairments: A Review. Japanese Journal of Special Education, 47, 163-171.

Ciarrochi, J., Heaven, P. C., \& Davies, F. (2007). The impact of hope, self-esteem, and attributional style on adolescents' school grades and emotional well-being: A longitudinal study. Journal of Research in Personality, 41, 1161-1178. doi:10.1016/j.jrp.2007.02.001

Cleary, T. J. (2012). Emergence of self-regulated learning microanalysis: historical overview, essential features, and implications for research and practice. In B. Zimmerman \& D. Schunk (Eds.), Handbook of SelfRegulation of Learning and Performance (pp. 329 -345). New York, NY: Routledge.

Goswami, U. (2015). Children's cognitive development and learning. Cambridge: Cambridge Primary Review Trust.

Coutinho, S. (2008). Self-efficacy, metacognition, and performance. National American Journal Psychology, 10, $165-172$.

Coutinho, S. A., \& Neuman, G. (2008). A model of metacognition, achievement goal orientation, learning style and self-efficacy. Learning Environments Research, 11(2), 131-151. http://dx.doi.org/10.1007/s10984-008-9042-7

Creamer, M., O’Donnell, M. L., Carbon, I., Lewis, V., Densley, K., \& McFarlane, A. (2009). Evaluation of the dispositional hope scale in injury survivors. Journal of Research in Personality, 43, 613-617.

Csíkos, C., \& Steklács, J. (2010). Metacognition-based reading intervention programs among 4th-grade Hungarian students. In A. Efklides \& P. Misailidi (Eds.), Trends and Prospects in Metacognition Research (pp. 345-366). New York: Springer Science + Business Media.

Curry, L. A., Snyder, C. R., Cook, D. L., Ruby, B. C., \& Rehm, M. (1997). The role of hope in student-athlete academic and sport achievement. Journal of Personality and Social Psychology, 73, 1257-1267.

De, C. A., Desoete, A., \& Roeyers, H. (2000). EPA2000: A multilingual, programmable computer assessment of off-line metacognition in children with mathematical-learning disabilities. Behavior Research Methods, Instruments, \& Computers, 32(2), 304-311. 10.3758/BF03207799

Desoete, A., Roeyers. H., \& Buysse, A. (2001). Metacognition and mathematical problem solving in grade 3. Journal of Learning Disabilities, 34, 435-449. 10.1177/002221940103400505

Desoete, A., Roeyers, H., \& De Clercq, A. (2003). Can offline metacognition enhance mathematical problem solving? Journal of Educational Psychology, 95, 188-200.

Dimmitt, C., \& McCormick, C. B. (2012). Metacognition in Education. In K. R. Harris, S. Graham, \& T. Urdan (Eds.), Educational Psychology Handbook (57-187). Washington, DC: APA.

Dixson, D. D. (2017). Hope across achievement: Examining psychometric properties of the children's hope scale across the range of achievement. SAGE Open, 7. 2158244017717304 http://dx.doi.org/10.1177/2158244017717304.

Dixson, D. D., Worrell, F. C., Olszewski-Kubilius, P., \& Subotnik, R. F. (2016). Beyond perceived ability: The contribution of psychosocial factors to academic performance: Psychosocial variables in outstanding performance. Annals of the New York Academy of Sciences, 1377, 67-77. http://dx.doi.org/10.1111/nyas.13210

Dunlosky, J., \& Metcalfe, J. (2009). Metacognition. Thousand Oaks, CA: Sage.

Eccles, J. S. \& Roeser, R.W. (2011). Schools as developmental contexts during adolescence. Journal of Research on Adolescence, 21(1), 225-241.

Eccles, J. S., \& Wigfield, A. (2000). Schooling influence on motivation and achievement. In S. Danziuger \& J. Waldfogel (Eds.), Securing the future: Investing in children from birth to college (pp. 153-181). New York: Sage.

Edwards, L., Rand, K. 1., Lopez, S. J., \& Snyder, C. A. (2007). Understanding Hope: A Review of Measurement and Construct Validity Research. In A. D. Ong \& H. M. van Dulmen (Eds.), Oxford Handbook of Methods in Positive Psychology (pp. 83-95). New York: Oxford University Press

Efklides, A. (2001). Metacognitive experiences in problem solving: Metacognition, motivation, and self-regulation. In A. Efklides, J. Kuhl, \& R. M. Sorrentino (Eds.), Trends and Prospects in Motivation Research (pp. 297-323). Dordrecht, The Netherlands: Kluwer Academic Publishers. 
Efklides, A. (2008). Metacognition: Defining its facets and levels of functioning in relation to self-regulation and co-regulation. European Psychologist, 13(4), 277-287.

Efklides, A. (2011). Interactions of metacognition with motivation and affect in self-regulated learning: The MASRL model. Educational Psychologist, 46, 6-25.

Efklides, A. (2014). How Does Metacognition Contribute to the Regulation of Learning? An Inte-grative Approach. Psychological Topics 23(1), 1-30.

Efklides, A. (2016). Affect and metacognition: Why their interactions are important for SRL. Keynote speech at the 15th ICM. Greece, Thessaloniki.

Efklides, A., \& Misailidi, P. (2010). Introduction: The Present and the Future in Metacognition. In A. Efklides \& P. Misailidi (Eds.), Trends and Prospects in Metacognition Research (pp. 1-20). New York, US: Springer Science + Business Media.

Feldman, D. B., \& Kubota, M. (2015). Hope, self-efficacy, optimism, and academic achievement: Distinguishing constructs and levels of specificity in predicting college grade-point average. Learning and Individual Differences, 37, 210-216. doi:10.1016/j.lindif.2014.11.022

Flavell, J. H. (1979). Metacognition and cognitive monitoring: A new area of cognitive-developmental inquiry. American Psychologist, 34(10), 906-911.

Flavell, J. H. (1987). Speculations about the nature and development of metacognition. In F. Weinert and R. Kluwe (Eds.), Metacognition, motivation and understanding (pp. 21-29). Hillsdale, NJ: Erlbaum.

Flavell, J. H., Miller, P. H., \& Miller, S. A. (2002). Cognitive development (4th ed.). Upper Saddle River, NJ: Prentice Hall.

Gallagher, M. W., Marques, S. C., \& Lopez, S. J. (2017). Hope and the Academic Trajectory of College Students. Journal of Happiness Studies, 18, 341. https://doi.org/10.1007/s10902-016-9727-z

Gallagher, M. W., \& Lopez, S. J. (2008). Hope, self-efficacy, and academic success in college students. Poster presented at the annual convention of the American Psychological Association. Boston.

Gaskill, P. J., \& Hoy, A. W. (2002). Self-efficacy and self-regulated learning: The dynamic duo in school performance. In J. Aronson (Ed.), Improving academic achievement: Impact of psychological factors on education (pp. 185-208). San Francisco: Academic Press.

Gibb, J. (1990). The Hope Scale revisited: Further validation of a measure of individual differences in the hope motive. Unpublished master's thesis, University of Illinois at Urbana-Champaign.

Gilman, R., Dooley, J., \& Florell, D. (2006). Relative levels of hope and their relationship with academic and psychological indicators among adolescents. Journal of Social and Clinical Psychology, 25, 166-178. doi:10.1521/jscp.2006.25.2.166

Gist, M. E., \& Mitchell, T. R. (1992). Self-efficacy: A theoretical analysis of its determinants and malleability. The Academy of Management Review, 17(2), 183-211. http://dx.doi.org/10.2307/258770

Glynou, E., Schwarzer, R., \& Jerusalem, M. (1994). Greek version of the General Self-Efficacy Scale. Available at www.RalfSchwarzer.de

Gomes, C. M. A., Golino, H. F., \& Menezes, I. G. (2014). Predicting School Achievement Rather than Intelligence: Does Metacognition Matter? Psychology, 5, 1095-1110. http://dx.doi.org/10.4236/psych.2014.59122

Gollwitzer, P. M. (1999). Implementation intentions: Strong effects of simple plans. American Psychologist, 54, 493-503.

Gallup. (2009). Hope, engagement, and well-being as predictors of attendance, credits earned, and GPA in high school freshmen. Unpublished data. Omaha, Nebraska.

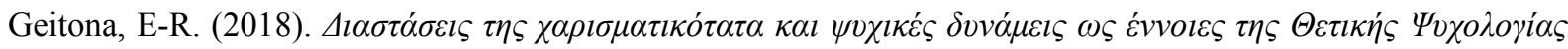
[in Greek, Dimensions of giftedness and psychic powers as concepts of Positive Psychology.]. Master thesis. University of Ioannina, Greece

Gourgey, A. (2010). Metacognition in basic skills instruction. In H. J. Hartman (Ed.), Metacognition in learning and instruction (pp. 17-32). New York, NY: Springer.

Hacker, D. J. (1998). Metacognition: Definitions and empirical foundations. In D. J. Hacker, J. Dunlosky, \& A. C. 
Graesser (Eds.), Metacognition in educational theory and practice (pp. 1-23). Mahwah, NJ: Erlbaum.

Hacker, D. J., Bol, L., \& Bahbahani, K. (2008). Explaining calibration accuracy in classroom contexts: The effects of incentives, reflection, and explanatory style. Metacognition and Learning, 3, 101-121.

Handel, M., Artelt, C., \& Weinert, S. (2013). Assessing metacognitive knowledge: Development and evaluation of a test instrument. Journal for Educational Research, 5(2), 162-188

Harris, M. M. (2015). The Role of Metacognition in a Montessori Environment and the Effects on Academic Achievement. Ed.D. Union University, Jackson, MS.

Harris, K. R., Graham, S., Brindle, M., \& Sandmel, K. (2009). Metacognition and children's writing. In D. Hacker, J. Dunlosky, \& A. Graesser (Eds.), Handbook of metacognition in education (pp. 131-153). Mahwah, NJ: Lawrence Erlbaum.

Harris, K. R., Santangelo, T., \& Graham, S. (2010). Metacognition and strategies instruction in writing. In H. S. Waters \& W. Schneider (Eds.), Metacognition, strategy use, and instruction (pp. 227-255). New York: The Guilford Press.

Haselhuhn, C. W., Al-Mabuk, R., Gabriele, A., Groen, M., \& Galloway, S. (2007). Promoting positive achievement in the middle school: A look at teachers' motivational knowledge, beliefs, and teaching practices. Research in Middle Level Education, 30, 1-20.

Hellman, C. M., \& Gwinn, C. (2016). Camp HOPE as an intervention for children exposed to domestic violence: A program evaluation of hope and strength of character. Child and Adolescent Social Work Journal, 1-8.

Holland-Joyner, M. H., \& Kurtz-Costes, B. (1997). Metamemory development. In N. Cowan (Ed.), The development of memory in childhood (pp. 275-300). Hove, UK: Psychology Press.

Jackson, T., Weiss, K. E., Lundquist, J. J., \& Hooper, D. (2003). The impact of hope, procrastination, and social activity on academic performance of midwestern college student. Education, 124(2), 310-320.

Jacobs, J. E., \& Paris, S.G. (1987). Children's metacognition about reading: Issues in definition, measurement, and instruction. Educational Psychologist, 22, 225-278.

Jansen, M., Scherer, R., \& Schroeders, U. (2015). Students' self-concept and self-efficacy in the sciences: Differential relations to antecedents and educational outcomes. Contemporary Educational Psychology, 41(1), 13-24. doi:10.1016/j.cedpsych.2014.11.002

Karagiannides, Y., Barboukis, V., Gourgoulis, V., Kosta, G. \& Antoniou, P. (2015). The role of motivation and metacognition on the development of cognitive and affective responses in physical education lessons: a self-determination approach. Motricidade, 11(1), 135-150.

Kim, B., Zyromski, B., Mariani, M. Lee, S. M., \& Carey, J. C. (2016). Establishing the Factor Structure of the 18-Item Version of the Junior Metacognitive Awareness Inventory. Measurement and Evaluation in Counseling and Development, 1-11.

Kwon, P. (2000). Hope and dysphoria: The moderating role of defense mechanisms. Journal of Personality, 68 , 199-223.

Lackaye, T. D., \& Margalit, M. (2008). Self-Efficacy, Loneliness, Effort, and Hope: Developmental Differences in the Experiences of Students with Learning Disabilities and Their Non-Learning Disabled Peers at Two Age Groups. Learning Disabilities: A Contemporary Journal, 6, 1-20.

Lai, E. R. (2011). Metacognition: A Literature Review. Pearson Assessments Research Reports. http://www.pearsonassessments.com

Lai, Y., Zhu, X., Chen, Y., \& Li, Y. (2015). Effects of Mathematics Anxiety and Mathematical Metacognition on Word Problem Solving in Children with and without Mathematical Learning Difficulties. PLoS ONE 10(6): e0130570. https://doi.org/10.1371/journal.pone.0130570

Lee, W., Lee, M.-J., \& Bong, M. (2014). Testing interest and self-efficacy as predictors of academic self-regulation and achievement. Contemporary Educational Psychology, 39(2), 86-99. http://dx.doi.org/10.1016/j.cedpsych.2014.02.002

Levi, U., Einav, M., Ziv, O., Raskind, I., \& Margalit, M. (2014). Academic expectations and actual achievements: The roles of hope and effort. European Journal of Psychology of Education, 29(3), 367-386. http://dx.doi.org/10.1007/s10212- 013-0203-4

Liem, A. D., Lau, S., \& Nie, Y. (2008). The role of self-efficacy, task value, and achievement goals in predicting 
learning strategies, task disengagement, peer relationship, and achievement outcome. Contemporary Educational Psychology, 33(4), 486-512.

Lopez, S. J., Bouwkamp, J., Edwards, L. E., \& Teramoto Pedrotti, J. (2000, October). Making hope happen via brief interventions. Presented at the Second Positive Psychology Summit, Washington, DC.

Luszczynska, A., Gibbons, F. X., Piko, B., \& Teközel, M. (2004). Self-regulatory cognitions, social comparison, perceived peers' behaviors as predictors of nutrition and physical activity: A comparison among adolescents in Hungary, Poland, Turkey, and USA. Psychology and Health, 19(5), 577-593

Luszczynska, A., Gutiérrez-Doña, B., \& Schwarzer, R. (2005). General self-efficacy in various domains of human functioning: Evidence from five countries. International Journal of Psychology, 40(2), 80-89.

Luszczynska, A., Scholz, U., \& Schwarzer, R. (2005). The General Self-Efficacy Scale: Multicultural Validation Studies. The Journal of Psychology, 139(5), 439-457. DOI: 10.3200/JRLP.139.5.439-457

Luthans, F., \& Jensen, S. M. (2002). Hope: A positive strength for human resource development. Human Resource Development, 1, 304-322.

Magaletta, P. R., Oliver, J. M. (1999). The hope construct, will, and ways: Their relations with self-efficacy, optimism, and general well-being. Journal of Clinical Psychology, 55, 539-551.

Maier, J., \& Richter, T. (2014). Fostering multiple text comprehension: how metacognitive strategies and motivation moderate the text-belief consistency effect. Metacognition \& Learning, 9, 51-74. 10.1007/s11409-013-9111-x

Marques, S. C., Gallagher, M. W., \& Lopez, S. J. (2017). Hope- and Academic-Related Outcomes: A Meta-Analysis. School Mental Health, 9(3), 250-262. https://doi.org/10.1007/s12310-017-9212-9

Marques, S. C., Lopez, S. J., Fontaine, A. M., Coimbra, S., \& Mitchell, J. (2015). How Much Hope Is Enough? Levels of Hope and Students' Psychological and School Functioning. Psychology in the Schools, 52(4), 325-334.

Marques, S. C., Lopez, S. J., \& Pais-Ribeiro, J. L. (2011). Building Hope for the Future - A program to foster strengths in middle-school students. Journal of Happiness Studies, 12, 139-152.

Marques, S. C., Pais-Ribeiro, J. L., \& Lopez, S. J. (2009). Validation of a Portuguese version of the Children Hope Scale. School Psychology International, 30, 538-551. doi:10.1177/0143034309107069

Marques, S. C., Pais-Ribeiro, J. L., \& Lopez, S. J. (2011). The role of positive psychology constructs in predicting mental health and academic achievement in Portuguese children and adolescents: A 2-year longitudinal study. Journal of Happiness Studies, 12, 1049-1062. doi:10.1007/s10902-010-9244-4

Martini, R., \& Shore, B. M. (2008). Pointing to parallels in ability-related differences in the use of metacognition in academic and psychomotor tasks. Learning and Individual Differences, 18, 237-247.

Martocchio, J. J., \& Hertenstein, E. J. (2003). Learning orientation and goal orientation context: Relationships with cognitive and affective learning outcomes. Human Resource Development Quarterly, 14, 413-434.

Metallidou, P. (2009). Pre-service and in-service teachers' metacognitive knowledge about problem-solving strategies. Teaching and Teacher Education, 25, 76-82.

Midgley, C., Anderman, E., \& Hicks, L. (1995). Differences between elementary and middle school teachers and students: A goal theory approach. Journal of Early Adolescence, 15, 90-113.

Moores, T. T., Chang, J. C., \& Smith, D. K. (2006). Clarifying the Role of Self-Efficacy and Metacognition as Indicators of Learning: Construct Development and Test. The DATA BASE for Advances in Information Systems, 37(2 \& 3), 125-132. https://digitalscholarship.unlv.edu/met_fac_articles/8

Neuenhaus, N., Artelt, C., Lingel, K., \& Schneider, W. (2011). Fifth graders metacognitive knowledge: General or domain specific? European Journal of Psychology of Education, 26, 163-178.

Ong, A. D., Edwards, L. M., \& Bergeman, C. S. (2006). Hope as a source of resilience in later adulthood. Personality and Individual Differences, 41, 1263-1273.

Panaoura, A., \& Philippou, G. (2003). The construct validity of an inventory for the measurement of young pupils' metacognitive abilities in mathematics. Paper presented at the International Group for the Psychology of Mathematics Education Conference, Honolulu, HI.

Panadero, E. (2017). A Review of Self-regulated Learning: Six Models and Four Directions for Research. 
Frontiers in Psychology, 8, 422. doi:10.3389/fpsyg.2017.00422

Pajares, F., \& Kranzler, J. (1995). Self-efficacy beliefs and general mental ability in mathematical $\begin{array}{llll}\text { problem-solving. } & \text { Contemporary }\end{array}$ http://dx.doi.org/10.1006/ceps.1995.1029

Pedrotti, J. T., Edwards, L., \& Lopez, S. J. (2008). Promoting hope: Suggestions for school counselors. Professional School Counseling, 12, 100-107.

Perry, B. (2013). Metacognitive awareness: Impact of a metacognitive intervention in a pre-nursing course. Ph.D. thesis, Louisiana State University.

Peterson, S. J., Gerhardt, M. W., \& Rode, J. C. (2006). Hope, learning goals and task performance. Personality and Individual Differences, 40, 1099-1109.

Petosa, R. L., Suminski, R., \& Hortz, B. (2003). Predicting vigorous physical activity using social cognitive theory. American Journal of Health Behavior, 27, 301-310.

Pintrich, P. (2002). The role of metacognitive knowledge in learning, teaching, and assessing. Theory into Practice, 41, 219-226.

Pressley, M., Borkowski, J. G., \& Schneider, W. (1987). Cognitive strategies: Good strategy users coordinate metacognition and knowledge. In R. Vasta \& G. Whitehurst (Eds.), Annals of Child Development (Vol. 5, pp. 89-129). New York: JAI Press.

Pressley, M., Borkowski, J. G., \& Schneider, W. (1989). Good information processing: What it is and what education can do to promote it. International Journal of Educational Research, 13, 857-867.

Rand, K. L., (2018). Hope, Self-Efficacy, and Optimism: Conceptual and Empirical Differences. In M. W. Gallagher and S. J. Lopez (Eds.), The Oxford Handbook of Hope (pp. 45-59). New York: Oxford University Press.

Rand, K. L., \& Cheavens, J. S, (2009). Hope theory. In S. J. Lopez and C. R. Snyder (Eds.), Oxford handbook of positive psychology (323 - 333). New York: Oxford University Press.

Rand, K. L., Martin, A. D., \& Shea, A. M. (2011). Hope, but not optimism, predicts academic performance of law students beyond previous academic achievement. Journal of Research in Personality, 45, 683-686. doi:10.1016/j.jrp.2011.08.004

Richardson, M., Abraham, C., \& Bond, R. (2012). Psychological correlates of university students' academic performance: A systematic review and meta-analysis. Psychological Bulletin, 138, 353-387. doi: $10.1037 / \mathrm{a} 0026838$

Rose, S. E., \& Robinson, C. (2007). Distinguishing hope theory from self-efficacy, self-regulation, goal theory, and optimism. Unpublished manuscript. University of Alabama.

Rosman, T., Mayer, A., \& Krampen, G. (2015). Combining Self-Assessments and Achievement Tests in Information Literacy Assessment: Empirical Results and Recommendations for Practice. Assessment \& Evaluation in Higher Education, 40(5), 740-754.

Sang, B., Wang, X. Y. (2001). Metacognition and students' learning. Global Education, 12, 16-18.

Schneider, W. (2008). The development of metacognitive knowledge in children and adolescents: Major trends and implications for education. Mind, Brain, and Education, 2(3), 114-121.

Schneider, W. (2010). Metacognition and memory development in childhood and adolescence. In H. Salatas Waters \& W. Schneider (Eds.), Metacognition, strategy use, and instruction (pp. 54-81). New York, NY: Guildford Press.

Schneider, W., \& Artelt, C. (2010). Metacognition and mathematics education. The International Journal on Mathematics Education, 42, 149-161.

Schneider, W., \& Lockl, K. (2006). Entwicklung metakognitiver Kompetenzen im Kindes- und Jugendalter. In W. Schneider, C. F. Graumann, N. Birbaumer, \& B. Sodian (Eds.), Enzyklopädie der Psychologie: Entwicklungspsychologie (Vol. 2., pp. 721-767). Göttingen, Germany: Hogrefe.

Schraw, G. (1998). Promoting general metacognitive awareness. Instructional Science, 26, 113-125.

Schraw, G., Crippen, K. J., \& Hartley, K. (2006). Promoting Self-Regulation in Science Education: Metacognition as Part of a Broader Perspective on Learning. Research in Science Education, 36, 111-139. 
Schraw, G. \& Moshman, D. (1995). Metacognitive theories. Educational Psychology Review, 7(4), 351-371.

Schunk, D. H., \& Zimmerman, B. J. (2006). Competence and control beliefs: Distinguishing the means and ends. In Alexander P. A., Winne P. H. (Eds.), Handbook of educational psychology (2nd ed., pp. 349-367). Mahwah, NJ: Lawrence Erlbaum Associates.

Schwarzer, R. (2014). Documentation of the General Self-Efficacy Scale. Available at http://www.ralfschwarzer.de

Schwarzer, R., \& Jerusalem, M. (1995). Generalized Self-Efficacy scale. In J. Weinman, S. Wright, \& M. Johnston, Measures in health psychology: A user's portfolio. Causal and control beliefs (pp. 35-37). Windsor, UK: NFER-NELSON.

Serra, M. J., \& Metcalfe, J. (2009). Effective implementation of metacognition. In D. J. Hacker, J. Dunlosky, \& A. C. Graesser (Eds.), Metacognition in educational theory and practice (pp. 278-298). Mahwah, New Jersey: Lawrence Erlbaum Associates, Inc.

Sherer, M., Maddux. J. H., Mercandante. B., Prentice-Dunn, S., Jacobs. B., \& Rogers, R. W. (1982). The Self-Efficacy Scale; Construction and validation. Psychological Report, 51, 663-671.

Skaalvik, E. M., Federici R. A., \& Klassen R. M. (2015). Mathematics achievement and self-efficacy: relations with motivation for mathematics. International Journal of Education Research, 72, 129-136. 10.1016/j.ijer.2015.06.008

Smit, K., de Brabander, C. J., Boekaerts, M., \& Martens, R. L. (2017). The Self-Regulation of Motivation Motivational Strategies as Mediator between Motivational Beliefs and Engagement for Learning. International Journal of Educational Research, 82, 124-134.

Snyder, C. R (2000). Handbook of hope. Orlando FL: Academic press.

Snyder, C. R. (2002). Hope theory: Rainbows in the mind. Psychological Inquiry, 13, 249-275. doi:10.1207/S15327965PLI1304_01

Snyder, C. R. (2004). Hope and depression: A light in the darkness. Journal of Social \& Clinical Psychology, 23(3), 347-351

Snyder, C. R., Feldman, D. B., Shorey, H. S., \& Rand, K. L. (2002). Hopeful choices: A school counselor's guide to hope theory. Professional School Counseling, 5, 298-307.

Snyder, C. R., Harris, C., Anderson, J. R., Holleran, S. A., Irving, L. M., Sigmon, S.T., Yoshinobu, L., Gibb, J., Langelle, C., \& Harney, P. (1991). The will and the ways: Development and validation of an individual differences measure of hope. Journal of Personality and Social Psychology, 60, 570-583.

Snyder, C. R., Hoza, B., Pelham, W. E., Rapoff, M., Ware, L., Danovsky, M., Highberger, L., Rubinstein, H., \& Stahl, K. J. (1997). The development and validation of the Children's Hope Scale. Journal of Pediatric Psychology, 22(3), 399-421. DOI: 10.1093/jpepsy/22.3.399

Snyder, C. R., Irving, L., \& Anderson, J. R. (1991). Hope and health: Measuring the will and the ways. In C. R. Snyder, \& D. R. Forsyth (Eds.), Handbook of social and clinical psychology: The health perspective (pp. 285-305). Elmsford, NY: Pergamon Press.

Snyder, C. R., \& Lopez, S. J. (2005). Handbook of positive psychology. New York: Oxford University Press.

Snyder, C. R., \& Lopez, S. J., (2007). Positive psychology: The scientific and practical explorations of human strengths. Thousand Oaks, CA: Sage Publications.

Snyder, C. R., \& Lopez, S. J. (2009). Psicologia Positiva: Uma abordagem científica e prática das qualidades humanas [Positive Psychology: A Scientific and Practical Approach to Human Qualities]. Porto Alegre: Artmed.

Snyder, C. R., Rand, K. L, \& Sigmon, D. R. (2005). Hope theory: A Member of the Positive Psychology Family. In C. R. Snyder, \& S. J. Lopez (Eds.), Handbook of Positive Psychology (pp. 257 -276). Oxford: University Press.

Snyder, C. R., Shorey, H. S., Cheavens, J., Pulvers, K. M., Adams, V. H., III, \& Wiklund, C. (2002). Hope and academic success in college. Journal of Educational Psychology, 94, 820-826. doi:10.1037/0022-0663.94.4.820

Snyder, C. R., Shorey, H. S., \& Rand, K. L. (2006). Using hope theory to teach and mentor academically at-risk students. In W. Buskist \& S. F. Davis (Eds.), Handbook of the teaching of psychology (pp. 170-174). 
Hoboken, NJ: Blackwell Publishing. doi:10.1002/9780470754924.ch29

Soodla, P., Jõgi, A. L., \& Kikas, E. (2016). Relationships between teachers' metacognitive knowledge and students' metacognitive knowledge and reading achievement. European Journal Psychology Education, 32, 1-18. doi: 10.1007/s10212-016-0293-x

Sperling, R. A., Howard, B. C., Miller, L. A., \& Murphy, C. (2002). Measures of children's knowledge and regulation of cognition. Contemporary Educational Psychology, 27(1), 51-79.

Sperling, R. A., Richmond, A. S., Ramsay, C. M., \& Klapp, M. (2012). The Measurement and Predictive Ability of Metacognition in Middle School Learners. The Journal of Educational Research, 105(1), 1-7.

Stephanou, G. (2011). Children friendship: The role of hope in attributions, emotions and expectations. Psychology, 2(8), 875-888.

Stephanou, G. (2012). Students' school performance in Language and Mathematics: Effects of hope on attributions, emotions and performance expectations. International Journal of Psychological Studies, 4(2), 94-98.

Stephanou, G., \& Mpiontini, M. (2017). Metacognitive knowledge and metacognitive regulation in self-regulatory learning style, and in its effects on performance expectation and subsequent performance across diverse school subjects. Psychology, 8, 1941-1975.

Stevens, T., Olivarez, A., Lan, W. Y., \& Tallent-Runnels, M. K. (2004). Role of mathematics self-efficacy and motivation in mathematics performance across ethnicity. Journal of Education Research, 97, 208-222. 10.3200/JOER.97.4.208-222

Stipek, D. J., \& MacIver, D. (1989). Developmental change in children's assessment of intellectual competence. Child Development, 60, 521-538.

Taasoobshirazi, G., \& Farley, J. (2013). Construct validation of the physics metacognition inventory. International Journal of Science Education, 35(3), 447-459

Tanner, K. D. (2012). Feature Approaches to Biology Teaching and Learning. Promoting Student Metacognition. CBE—Life Sciences Education, 11, 113-120.

Tarricone, P. (2011). The taxonomy of metacognition. New York: Taylor \& Francis Group.

Tennen, H., Affleck, G., \& Tennen, R. (2002). Clipped feathers: The theory and measurement of hope. Psychological Inquiry, 13(4), 311-317.

Thillmann, H. (2008). Selbstreguliertes lernen durch experimentieren: Von der erfassung zur förderung. Doctoral dissertation, Universität Duisburg-Essen, Fakultät für Bildungswissenschaften» Institut für Psychologie» Lehr-Lernpsychologie.

Tian, Y., Fang. Y., \& Li, J. (2018). The Effect of Metacognitive Knowledge on Mathematics Performance in Self-Regulated Learning Framework-Multiple Mediation of Self-Efficacy and Motivation. Front Psychology, 9: 2518. doi: 10.3389/fpsyg.2018.02518

Valle, M. F., Huebner, E. S., \& Suldo, S. M. (2006). An Analysis of Hope as a Psychological Strength. Journal of School Psychology, 44, 393-406. https://doi.org/10.1016/j.jsp.2006.03.005

Valle, M. F., Huebner, E. S., \& Suldo, S. M. (2004). Further Evaluation of the Children's Hope Scale. Journal of Psychoeducational Assessment, 22, 320 - 337.

van der Stel, M., \& Veenman, M. V. J. (2014). Metacognitive skills and intellectual ability of young adolescents: A longitudinal study from a developmental perspective. European Journal of Psychology of Education, 29, $117-137$.

Veenman, M. V. J. (2011). Learning to self-monitor and self-regulate. In R. Mayer, \& P. Alexander (Eds.), Handbook of research on learning and instruction (pp. 197-218). New York: Routledge.

Veenman, M. V. J. (2016). Metacognition. In P. Afflerbach (Ed.), Handbook of Individual Differences in Reading: Reader, Text, and Context (pp. 26-40). London: Routledge.

Veenman, M. V. J., Kok, R., \& Blöte, A. (2005). The relation between intellectual and metacognitive skills in early adolescence. Instructional Science, 33, 193-211.

Veenman, M. V. J., \& Spaans, M. A. (2005). Relation between intellectual and metacognitive skills: Age and task. Learning and Individual Differences, 15, 159-176. 
Veenman, M. V. J., van Hout-Wolters, B. H. A. M., \& Afflerbach, P. (2006). Metacognition and learning: Conceptual and methodological considerations. Metacognition and Learning, 1, 3-14.

Veenman, M. V. J., Wilhelm, P., \& Beishuizen, J. J. (2004). The relation between intellectual and metacognitive skills from a developmental perspective. Learning and Instruction, 14(1), 89-109.

DOI: $\quad$ 10.1016/j.learninstruc.2003.10.004

Wang, Z., \& Han, F. (2017). Metacognitive knowledge and metacognitive control of writing strategy between high- and low-performing Chinese EFL writers. Theory and Practice in Language Studies, 7(7), 523-532.

Weil, L.G., Fleming, S. M., Dumontheil, I., Kilford, E. J., Weil, R. S., Rees, G., \& Blakemore, S. (2013). The development of metacognitive ability in adolescence. Consciousness and Cognition, 22, 264-271.

Winne, P. H., \& Nesbit, J. C. (2010). The psychology of academic achievement. Annual Review of Psychology, 61, 653-678. http://doi.org/10.1146/annurev.psych.093008.100348

Yotsidi, V., Pagoulatou, A., Kyriazos, T., \& Stalikas, A. (2018). The Role of Hope in Academic and Work Environments: An Integrative Literature Review. Psychology, 9, 385-402. https://doi.org/10.4236/psych.2018.93024

Yeo, G. B. \& Neal, A. (2006). An Examination of the Dynamic Relationship Between Self-Efficacy and Performance Across Levels of Analysis and Levels of Specificity. Journal of Applied Psychology, 91(5), $1088-1101$

Young, A. E. (2010). Explorations of Metacognition Among Academically Talented Middle and High School Mathematics Students. Ph.D. Thesis, University of California, Berkeley.

Zepeda, C. D., Richey, J. E., Ronevich, P., \& Nokes-Malach, T. J. (2015). Direct instruction of metacognition benefits adolescent science learning, transfer, and motivation: An in vivo study. Journal of Educational Psychology, 107(4), 954-970. http://dx.doi.org/10.1037/edu0000022

Zimmerman, B. J. (2000). Attainment of self-regulation: A social cognitive perspective. In M. Boekaerts, P. Pintrich, \& M. Zeidner (Eds.), Handbook of self-regulation (13-39). Orlando, FA: Academic Press.

Zimmerman, B. J. (2002). Becoming a self-regulated learner: An overview. Theory into Practice, 41(2), 64-70.

Zimmerman, B. J. (2008). Investigating self-regulation and motivation: Historical background, methodological developments, and future prospects. American Educational Research Journal, 45(1), 166-183.

Zimmerman, B. J., \& Schunk, D. H. (2011). Self-regulated learning and performance. In B. J. Zimmerman and D. H. Schunk (Eds.), Handbook of self-regulation of learning and performance (pp. 1-12). New York: Routledge.

Zohar, A., \& David, B. A. (2009). Paving a clear path in a thick forest: A conceptual analysis of a metacognitive component. Metacognition and Learning, 4(3), 177-195.

Zohar, A., \& Peled, B. (2008). The effects of explicit teaching of metastrategic knowledge on low- and high-achieving students. Learning and Instruction, 18, 337-353. 10.1016/j.learninstruc.2007.07.001

\section{Copyrights}

Copyright for this article is retained by the author(s), with first publication rights granted to the journal.

This is an open-access article distributed under the terms and conditions of the Creative Commons Attribution license (http://creativecommons.org/licenses/by/4.0/). 